\title{
IGF-Related Proteins at Birth in a Case of Antenatally Diagnosed Silver-Russell Syndrome
}

\author{
KOTARO FUKUSHIMA, HAJIME KOMATSU, MEGUMI MATSUMOTO, HIROAKI KOBAYASHI, \\ KIYOMI TSUKIMORI, SHOJI SATOH, AND HITOO NAKANO \\ Department of Obstetrics and Gynecology, Graduate School of Medical Sciences, Kyushu University, \\ Fukuoka, Japan [K.F., Ha.K., M.M., Hi.K., K.T., H.N.]; Maternity and Perinatal Care Unit, Kyushu \\ University Hospital, Fukuoka, Japan [S.S.]
}

\begin{abstract}
ABSTR
We report here a case with severe intrauterine growth restric-
tion from the first trimester and clinical features of Silver-Russell
syndrome including microcephaly, low-set ear, atrial septum
defect, ventricular septum defect, diaphragmatic relaxation, and
rocker bottom feet. Silver-Russell syndrome is thought to result
from deletion of the distal long arm of chromosome 15 on which
the IGF-I receptor (IGF-IR) gene is located. We measured both
the maternal and cord blood levels of GH, IGF-I, and IGF-
binding protein and performed an immunohistochemical study of
IGF-IR in the placenta to investigate whether these IGF-related
proteins were affected in this patient. The hormonal level of these
proteins did not significantly differ from normal neonates, and
\end{abstract}
Silver-Russell syndrome is one of the clinical entities causing severe IUGR. Monosomy of the IGF-IR gene resulting from deletion of the distal long arm of chromosome 15 has been identified in patients presenting with features of SilverRussell syndrome (1). Sieblar et al. (2) report decreased IGF-IR receptor number and mRNA expression in cultured fibroblasts from two patients diagnosed with this syndrome shown to be hemizygous for the IGF-IR gene. These findings demonstrate that loss of even a single copy of the IGF-IR gene could cause severe growth defects.

IGFs and their binding proteins (IGFBPs) are thought to have an important role in fetal growth (3). Several reports have provided evidence of abnormalities of the IGF-IR in patients with short stature (4-6). The IGF-related proteins null mice show severe defects in intrauterine growth (7) and multiple investigators have reported low levels of IGF-I at birth in IUGR fetuses (8-10). Taken together, these studies support the hypothesis that IGF-related proteins play a key role in fetal development. Based on this model, one might

Received February 13, 2001; accepted July 23, 2001.

Correspondence: Kotaro Fukushima, MD, PhD, Department of Obstetrics and Gynecology, Graduate School of Medical Sciences, Kyushu University, 3-1-1 Maidashi, Higashi-ku, Fukuoka 812-8582, Japan; e-mail: kfuku@gynob.med.kyushu-u.ac.jp

Supported, in part, by a grant-in-aid from the Ministry of Education (12671608, 12671613). immunohistochemical analysis suggested IGF-IR protein levels in the placenta were comparable to normal term neonates. These results support the hypothesis that growth insufficiency could occur in patients with monosomy of the distal long arm of chromosome 15 and suggest a critical threshold for IGF-related fetal growth in early pregnancy. (Pediatr Res 51: 323-327, 2002)
IGFBP, IGF binding protein
Abbreviations
IGF-IR, IGF I receptor
IUGR, intrauterine growth restriction

expect patients with Silver-Russell syndrome to have abnormal levels of hormonal and cellular IGF-related proteins. Unfortunately, there has been limited information on serum hormone levels for patients with this syndrome. The $\mathrm{GH}$ and IGF-I levels reported in infants are essentially normal except for one report of a single elevated measurement at $2 \mathrm{y}$ of age (3). There has been no information in the published literature concerning hormone levels at birth in patients diagnosed with this syndrome.

We have diagnosed antenatally a case of partial monosomy of chromosome 15 associated with features of Silver-Russell syndrome. The fetus showed several deformities and severe IUGR occurred in the first trimester. To investigate the profile of the IGF axis in this case, we measured IGF-related protein levels in cord blood and performed IGF-IR staining in the placenta.

\section{CASE PRESENTATION}

A 27-y-old Japanese woman, gravida 1, para 0, went to a private gynecologist and was diagnosed to be at $6 \mathrm{wk}$ of gestation. At 9 wk of gestation, the expected date of delivery was confirmed by crown-rump length. From 13 wk of gestation, the fetal biparental diameter (BPD) was sustained around the mean $-2.5 \mathrm{SD}$. Although amniocentesis was performed to exclude chromosomal abnormality, fetal karyotype was diag- 
nosed as normal, 46XX. She was referred to our hospital under the diagnosis of severe IUGR at $28 \mathrm{wk}$ of gestation.

On admission, the estimated fetal body weight was $580 \mathrm{~g}$ (mean $-3 \mathrm{SD}$ ). Maternal vascular disease, maternal metabolic disorders, and fetomaternal infectious diseases were excluded. Oligohydramnios, tetralogy of Fallot, single umbilical artery, and diaphragmatic relaxation were suspected by ultrasound scan. Amniocentesis was repeated and precise fetal karyotype analysis using GTG-banded analysis and fluorescent in situ hybridization (FISH) analysis confirmed the chromosomal aberration of 46XX, der (15) t (15; ?) (q26; ?), ish der (15) (wcp215-, D15S396-) (Fig. 1).

After counseling and discussion with the patient and her husband, we kept the patient in ward to monitor the fetus closely. The parents desired active resuscitation and intensive treatment for the neonate. At $38 \mathrm{wk}$ of gestation, fetal growth was judged to have ceased and labor was induced. A cesarean section was performed in response to nonreassuring fetal status with impending profound hypoxemia indicated by cardiotocogram. The baby weighed $898 \mathrm{~g}$ with cord blood pH of 7.356 and an Apgar score of 6 and 7 at 1 and $5 \mathrm{~min}$, respectively. The placenta weighed $120 \mathrm{~g}$ and appeared histologically normal. The baby showed the phenotype of Silver-Russell syndrome with microcephaly, low-set ear, atrial septum defect, ventricular septum defect, diaphragmatic relaxation, and rocker bottom feet and was referred to the neonatal intensive care unit. The baby was treated with nitrogen oxide, prostaglandins, digitalization, and high-frequency oxygenation due to persistent heart failure and pulmonary hypertension. She died from circulation failure on d 135 after birth.

Both the patient and her husband underwent chromosomal analysis after delivery and it was determined that the husband had a translocation of 46XY t $(15,18)$ (q26: p11.2) (Fig. 2).

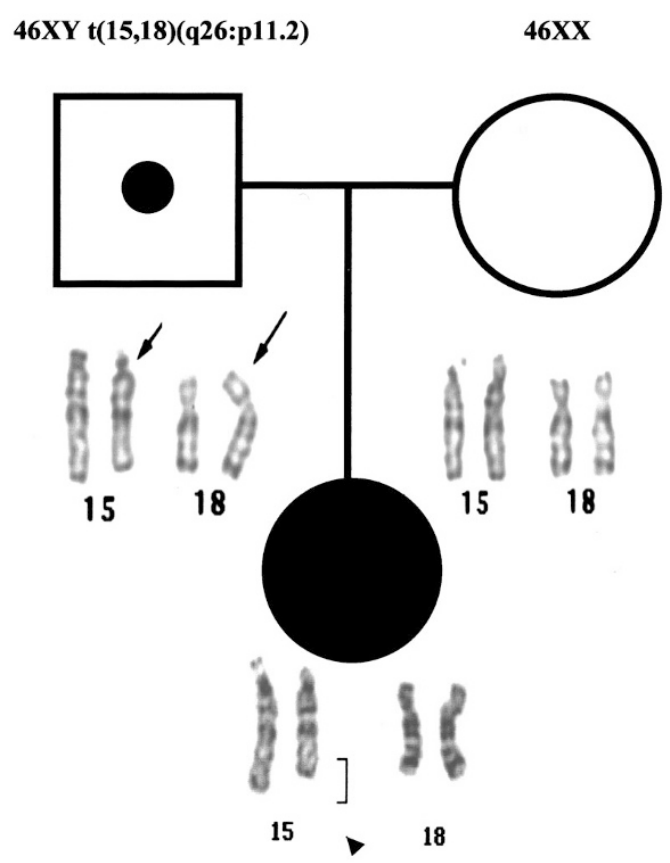

46XX, der (15) t (15; ?) (q26; ?), ish der(15)(wcp215-,D15S396-)

Figure 2. GTG-banded chromosome $15 \mathrm{~s}$ and $18 \mathrm{~s}$ from the father, mother, and child. Translocation (father) and derivation (baby) are indicated with an arrow and an arrowhead, respectively.

\section{MATERIALS AND METHODS}

\section{Measurement of GH, IGF-I, and IGFBP3 and Immunohistochemical Study}

All analysis was performed after obtaining consent from the parent and the study was approved by the applicable institutional review board.

To measure GH, IGF-I, and IGFBP3, RIA was performed using the commercially available GH-kit (Daiichi Radioisotope

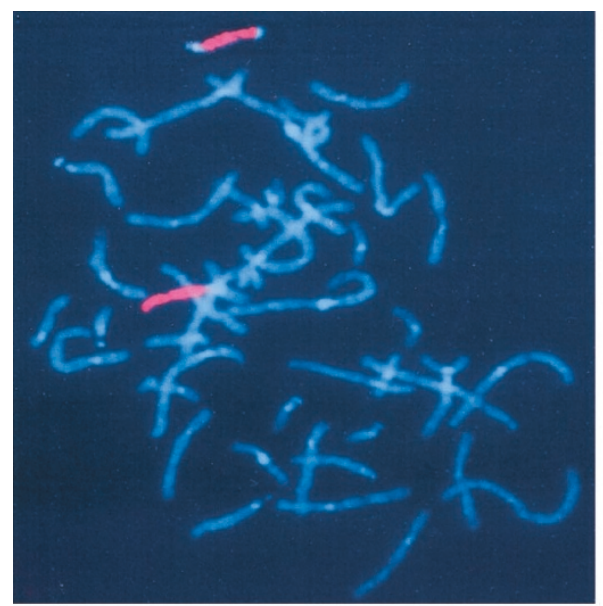

15 PAINT(v)

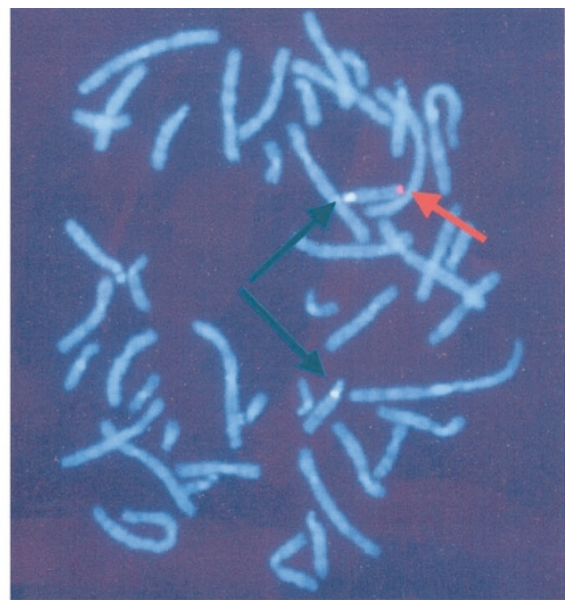

D15Z(o)(g)/D15S396(v)(r)

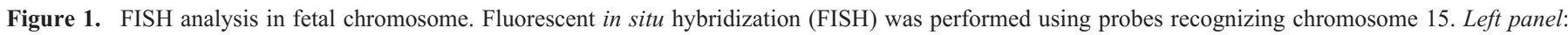

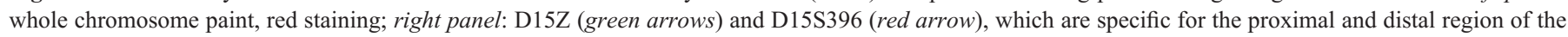
chromosome 15 , respectively. 
Laboratories, Kenkyusho, Tokyo, Japan), Somatomedine C (II) (Byel Medical, Tokyo, Japan), and IGFBP3-IRMA (Daiichi Radioisotope), respectively. All measurements were performed by a commercial service (BML, Tokyo, Japan)

Immunohistochemical analysis for IGF-IR in placenta was performed by the labeled polymer method using the EnVision+ kit (DAKO, Carpinteria, CA, U.S.A.). Placental tissue excised through the full thickness immediately after delivery was formalin-fixed and paraffin-embedded. Four-micrometer sections were deparaffinized and rehydrated. After blocking endogenous peroxidase with $0.3 \%$ hydrogen peroxidase in methanol for $30 \mathrm{~min}$, slides were washed and microwaved for $15 \mathrm{~min}$ in $10 \mathrm{mM}$ citrate buffer ( $\mathrm{pH}$ 6.0) to enhance antigen detection. Slides were then incubated with rabbit anti-IGF-IR $\alpha$ polyclonal antibody (diluted 1:100; Santa Cruz Biochemicals, Santa Cruz, CA, U.S.A.) for $60 \mathrm{~min}$ and exposed to goat anti-rabbit Ig conjugated to peroxidase-labeled dextran polymer for 20 min, followed by staining with 3,3'-diaminobenzidine tetrahydrochloride. Counterstaining with hematoxylin followed. Normal full-term placenta was used as a positive control.

\section{RESULTS}

Table 1 shows GH, IGF-I, and IGFBP3 levels from cord blood and maternal blood taken just after delivery. All hormonal levels were essentially normal in both maternal vein and cord blood.

To address whether fetal IGF-IR protein expression was affected, we performed immunohistochemical staining with anti-IGF-IR antibody in the placenta of the patient and normal full-term controls. These controls were confirmed to have normal karyotype. Surprisingly, the expression of IGF-IR was not different between the patient and controls (Fig. 3).

\section{DISCUSSION}

Herein we reported profiles of IGF-related proteins at delivery in a case of antenatally diagnosed distal $15 q$ deletion. Although we could not perform Southern blot analysis on the IGF-IR gene, the clinical phenotype corresponded to that of Silver-Russell syndrome (1). FISH analysis confirmed the deletion of distal chromosome 15q (Fig. 1), and the aberrant chromosome is considered derived from paternal translocation, 18p. Silver-Russell syndrome, as well as ring chromosome 15 syndrome, are both associated with

Table 1. Hormonal profiles in maternal and cord blood at delivery

\begin{tabular}{lrrrrr}
\hline & \multicolumn{2}{c}{ Maternal vein } & & \multicolumn{2}{c}{ Cord Blood } \\
\cline { 2 - 3 } \cline { 5 - 6 } & Present case & Normal range & & Present case & Normal range \\
\hline GH & NE & & & $32.1 \mathrm{ng} / \mathrm{mL}$ & $29.5 \pm 14.7^{*}$ \\
IGF-I & $131.7 \mathrm{ng} / \mathrm{mL}$ & $179.4 \pm 28.2 \dagger$ & & $39.9 \mathrm{ng} / \mathrm{mL}$ & $61.6 \pm 39.5^{*}$ \\
IGFBP-3 & $3.2 \mu \mathrm{g} / \mathrm{mL}$ & $3.95 \pm 0.09 \ddagger$ & & $1.2 \mu \mathrm{g} / \mathrm{mL}$ & $1.25 \pm 0.4^{*}$ \\
\hline
\end{tabular}

Maternal and cord blood samples were taken at delivery and measured as described in "Materials and Methods." Normal range was presented means \pm either SD or SE except IGF-I in cord blood.

$\mathrm{NE}$, not examined.

* Yang et al. 11; † Guidice et al. 12; † Pirazzoli et al. 13.

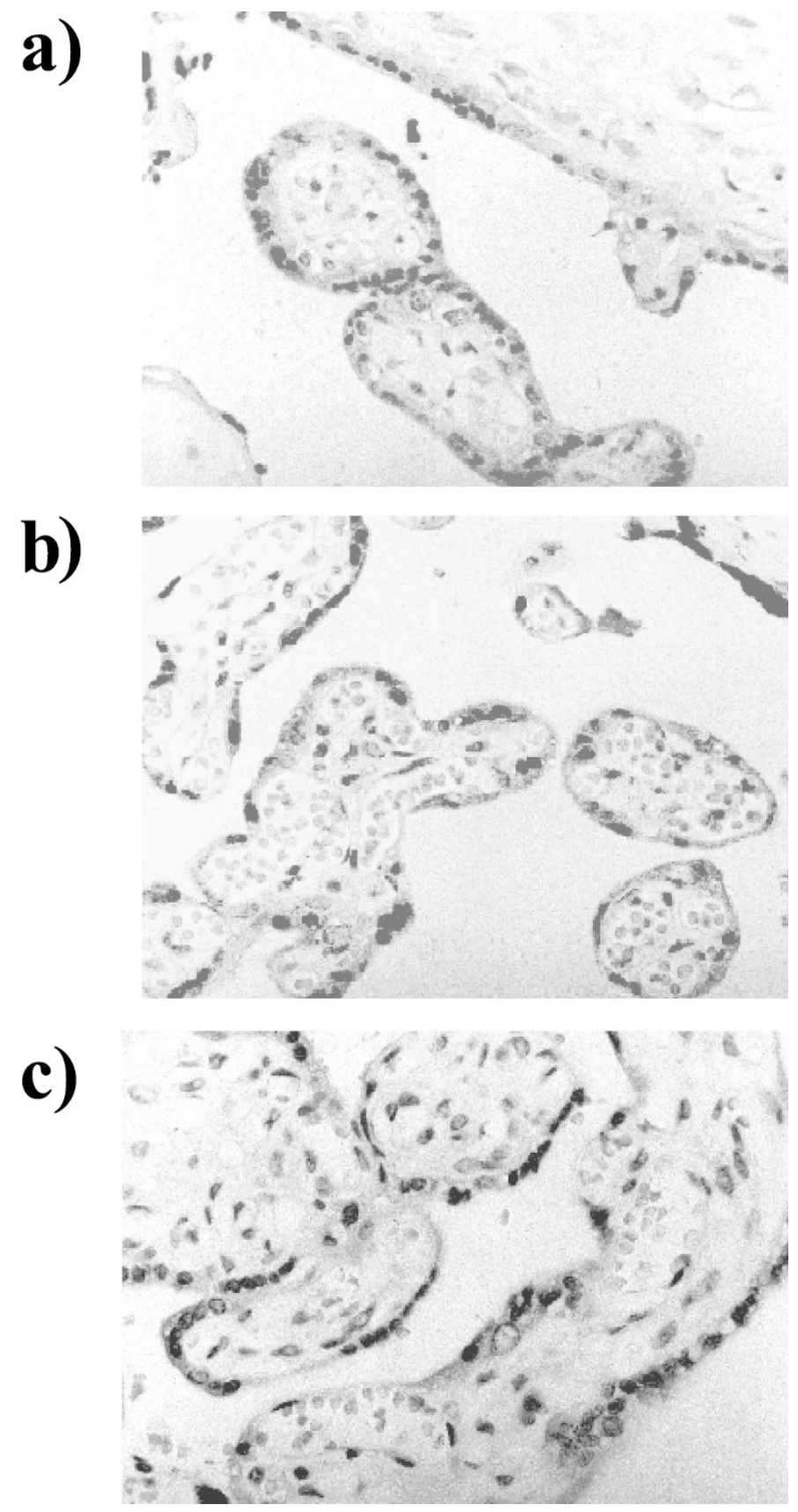

Figure 3. Immunohistochemical staining against IGF-I receptor. Each block of tissues was collected immediately after delivery and prepared as described in "Materials and Methods." The tissues were then stained by anti-IGF-IR antibody and visualized by horseradish peroxidase labeling. The expression of IGF-IR was not different between the patient and controls. (a) Patient's placenta; $(b)$ and $(c)$ placenta from normal full-term delivery. Magnification $\times 400$.

terminal $15 q$ deletions $(1,11)$ thought to result in IUGR and postnatal growth failure in addition to other developmental abnormalities. It has been proposed that absence of one copy of the IGF-IR gene located on the affected chromosome in these syndromes plays a major role in growth insufficiency $(3,12)$. There have been many reports on IGF-related proteins in cord and maternal blood during pregnancy, suggesting a correlation between these proteins and fetal growth (8-10). Experiments using knockout mice provided 
Table 2. Comparison of fetal abnormalities in the present case and previous reports

\begin{tabular}{|c|c|c|c|}
\hline & $\begin{array}{l}\text { Distal deletion of } 15 \mathrm{q} \\
\qquad(n=8)^{*}\end{array}$ & $\begin{array}{l}\text { Ring choromosome } 15 \text { syndrome } \\
\qquad(n=28)^{*}\end{array}$ & Present case \\
\hline Oligohydramnios & $3 / 3$ & NR & + \\
\hline IUGR & $6 / 8$ & $19 / 27$ & + \\
\hline Microcephaly & $5 / 6$ & $22 / 25$ & + \\
\hline Hypertelorism & $4 / 4$ & $12 / 25$ & - \\
\hline High-arched palate & $5 / 6$ & $7 / 28$ & - \\
\hline \multicolumn{4}{|l|}{ Eyes } \\
\hline Microophtalamia & $1 / 3$ & NR & - \\
\hline Hypopigmented iris & $3 / 4$ & NR & - \\
\hline \multicolumn{4}{|l|}{ Cardiopulmonary } \\
\hline Cardiac abnormality & $2 / 5$ & $8 / 28$ & ASD, VSD \\
\hline Lung hypoplasia & $4 / 6$ & $1 / 1$ & + \\
\hline Clinodactyly & $4 / 4$ & $8 / 28$ & - \\
\hline Proximal placement of thumb or toe & $4 / 4$ & NR & - \\
\hline Clubfeet & $2 / 2$ & $4 / 28$ & Rocker bottom feet \\
\hline Kyphosis or scoliosis & $2 / 3$ & NR & - \\
\hline
\end{tabular}

* Modified from the cases reviewed in Roback et al. 1 .

$\mathrm{NR}$, not reported; ASD, atrial septum defect; VSD, ventricular septum defect

support that IGF systems play a major role in antenatal/ postnatal growth $(7,13)$. Taken together, it is most likely that loss of one copy of IGF-IR is involved in the pathophysiology of the present case.

Lacking one copy of the IGF-IR gene might be expected to cause primary IGF-I resistance through a quantitative deficiency of the receptor, resulting in end-organ insensitivity and negative feedback by IGF-I levels (3). However, in the present case, there was no significant elevation in IGF-I level in cord blood, nor was any evidence of negative feedback found. The GH and IGFBP3 levels were also normal. There has been limited information on serum hormone levels in patients diagnosed with this syndrome (Table 2 ) and the GH and IGF-I levels reported in infants are essentially normal except for a single elevated measurement at $2 \mathrm{y}$ of age (3). There has been no information in the published literature concerning hormone levels at birth for this syndrome. Our results indicated that IGF-related protein levels were essentially normal in Silver-Russell syndrome even at birth.

No significant differences in IGF-IR expression were observed in the immunohistochemical staining of the placenta when compared with normal controls. Holmes et al. (14) detected IGF-IR in endothelial cells, stromal cells, trophoblasts, and deciduas and the intensity of staining was not different among small-for-gestational-age neonates, IUGR, and normal controls. The independence of placental IGF-IR levels to changes in fetal growth was also reported by Culler et al. (15). Sieblar et al. (2) reported decreased IGF-IR receptor number and mRNA expression in cultured fibroblasts from two patients hemizygous for the IGF-IR gene, but they could not find any impaired biologic response to IGF-I in these cells. These findings suggested that there might be another essential mechanisms in IGF-I-IGF-IR function as well as the amount of receptor protein. Unfortunately, we could not assess the exact amount of IGF-IR protein from our immunohistochemical analysis. However, it may be assumed that there is a critical threshold for IGF in determining fetal growth at the early phase of pregnancy because the growth restriction began in the first trimester.

We analyzed IGF-related proteins in cord blood and IGF-IR expression in placenta at birth in a case of Silver Russell syndrome diagnosed antenatally with monosomy of the distal long arm of chromosome 15 resulting in growth insufficiency and phenotypic diagnosis of Silver-Russell syndrome. We did not observe reduced IGF-IR expression nor was negative feedback in IGF axis demonstrated. This result supports previous studies of affected infants and suggests that normal protein levels are present at birth $(16-18)$.

Acknowledgment. The authors thank Dr. H. Nakayama, Maternity and Perinatal Care Unit, Kyushu University Hospital, for information about neonatal management.

\section{REFERENCES}

1. Roback EW, Barakat VG, Mbikay DM, Chretien M, Butler MG 1995 An infant with deletion of the distal long arm of chromosome 15 (q26.1 $\rightarrow$ qter) and loss of insulin like growth factor 1 receptor gene. Am J Med Genet 38:74-79

2. Siebler T, Lopaczynski W, Terrry CL, Casella SJ, Munson PM, Leon DD, Phang L, Blakemore KJ, Mcevoy RC, Kelley R, Nissley P 1995 Insulin like growth factor 1 receptor expression and function in fibroblasts from two patients with deletion of the distal long arm of chromosome 15. J Clin Endo Metabol 80:3447-3457

3. Jain S, Goled DW, Bailey R, Geffner ME 1998 Insulin like growth factor 1 resistance. Endocr Rev 19:625-646

4. Bierich FR, Moeller H, Ranke MB, Rosenfeld RG 1984 Pseudopituitary dwarfism due to resistance to somatomedin; a new syndrome. Eur J Pediatr 142:186-188

5. Van Obberghen-Schilling EE, Rechler MM, Romanus JA, Knight AB, Nissley SP, Humbel RE 1981 Receptors for insulin-like growth factor I are defective in fibroblasts from a patient with leprechaunism. J Clin Invest 68:1356-1365 
6. Geffner ME, Bailey RC, Bersch N, Vera JC, Golde DW 1993 Insuline like growth factor I unresponsiveness in an Efe pygmy. Biophysis Res Commun 13:566-595

7. Baker J, Liu JP, Robertson E, Efstratiadis A 1993 Role of growth factors in embryonic and postnatal growth. Cell 75:73-82

8. Hills FA, English J, Chard T 1996 Circulating levels of IGF-I and IGF-binding protein throughout pregnancy: relation to birth weight and maternal weight. J Endocrinol 148:303-309

9. Bennett Am, Wilson DM, Liu F, Nagashima R, Rosenfeld RG, Hintz RL 1983 Levels of insulin like growth factors 1 and 2 in human cord blood. J Clin Endocrinol Metabol 57:609-612

10. Lassarre C, Hardouin S, Daffos F Forestier F, Frankenne F, Binoux M 1991 Serum insulin-like growth factors and insulin-like growth factor binding proteins in the human fetus: relationships with growth in normal subjects and in subjects with intrauterine growth retardation. Pediatr Res 29:219-225

11. Yang SW, Yu JS 2000 Relationship of insulin-like growth factor 1, insulin-like growth factor binding protein 3 , insulin, growth hormone in cord blood and maternal factors with birth height and birth weight. Pediatr Int 42:31-36

12. Guidice LC, Martina NA, Crystal RA, Tazuke S, Druzin M 1997 Insulin-like growth factor binding protein-1 at the maternal-fetal interface and insulin-like growth factor-2 and insulin-like growth factor binding protein-1 in the circulation of women with severe preeclampsia Am J Obstet Gynecol 176:751-758
13. Pirazzoli P, Cacciari E, De Iasio R, Pittalis MC, Dallacasa P, Zucchini S, Guali, S Salardi S, David C, Boschi S 1997 Developmental pattern of fetal growth hormone, insulin-like growth factor 1, growth hormone binding protein and insulin-like growth factor binding protein 3. Arch Dis Child Fetal Neonatal Ed 77:100-104

14. Tamura T, Tohma T, Ohta T, Soejima H, Harada N, Abe K, Niikawa N 1993 Ring chromosome 1 involving deletion of the insulin-like growth factor 1 receptor gene in a patient with features of Silver-Russell syndrome. Clin Dysmorphol 2:106113

15. Alsat E, Marcotty C, Gabriel R, Igout A, Frankenne F, Hennen G, Evain-Brion D 1995 Molecular approach to intrauterine growth retardation: an overview of recent data. Reprod Fertil Dev 7:1457-1464

16. Accili D, Nakane J, Kim JJ, Park B, Rother KI 1999 Targeted gene mutations define the roles of insulin and IGF-I receptors in mouse embryonic development. J Pediatr Endocrinol Metab 12:475-485

17. Holmes R, Porter H, Newcomb P, Holly JMP, Soothill P 1999 An immunohistochemical study of type 1 insulin-like growth factor receptors in the placenta of pregnancies with appropriately grown of growth restricted fetuses. Placenta 20:325330

18. Culler FL, Tung RF, Jansons RA, Moiser HD 1996 Growth promoting peptides in diabetic and non-diabetic pregnancy: interactions with trophoblastic receptors and serum carrier proteins. J Pediatr Endocrinol Metab 9:21-29 